First Peoples Child \& Family Review

An Interdisciplinary Journal Honouring the Voices, Perspectives, and Knowledges of

First Peoples through Research, Critical Analyses, Stories, Standpoints and Media

Reviews

\title{
REDressing Invisibility and Marking Violence Against Indigenous Women in the Americas Through Art, Activism and Advocacy
}

\section{Shelly Johnson and Alessandra Santos}

Volume 7, Number 2, 2013

URI: https://id.erudit.org/iderudit/1068844ar

DOI: https://doi.org/10.7202/1068844ar

See table of contents

Publisher(s)

First Nations Child and Family Caring Society of Canada

ISSN

1708-489X (print)

2293-6610 (digital)

Explore this journal

Cite this article

Johnson, S. \& Santos, A. (2013). REDressing Invisibility and Marking Violence Against Indigenous Women in the Americas Through Art, Activism and Advocacy. First Peoples Child \& Family Review, 7(2), 97-111.

https://doi.org/10.7202/1068844ar

\section{Article abstract}

The incidence of crimes against Indigenous women in the Americas has a long history in the making, but in remembering this history now, in redressing the invisible violence, in rendering the invisible visible, is how we as community can put a stop to the atrocities. Two Indigenous women academics from north and south America explore the intersections between art, activism and advocacy in this article on missing, raped and murdered Indigenous women in Mexico, Guatemala and Canada. It asks questions and provides examples about how artists, activists and advocates can redress the invisibility of the violence against Indigenous women, violations of their human rights and potentially repair loss.
This document is protected by copyright law. Use of the services of Érudit (including reproduction) is subject to its terms and conditions, which can be viewed online.

https://apropos.erudit.org/en/users/policy-on-use/ 


\title{
First Peoples Child \& Family Review
}

An Interdisciplinary Journal Honoring the Voices, Perspectives and Knowledges of First Peoples through Research, Critical Analyses, Stories, Standpoints and Media Reviews

\section{REDressing Invisibility and Marking Violence Against Indigenous Women in the Americas Through Art, Activism and Advocacy}

\author{
Shelly Johnson ${ }^{a}$ and Alessandra Santos ${ }^{b}$ \\ Vancouver, BC, Canada \\ Vancouver, BC, Canada
}

\begin{abstract}
The incidence of crimes against Indigenous women in the Americas has a long history in the making, but in remembering this history now, in redressing the invisible violence, in rendering the invisible visible, is how we as community can put a stop to the atrocities. Two Indigenous women academics from north and south America explore the intersections between art, activism and advocacy in this article on missing, raped and murdered Indigenous women in Mexico, Guatemala and Canada. It asks questions and provides examples about how artists, activists and advocates can redress the invisibility of the violence against Indigenous women, violations of their human rights and potentially repair loss.
\end{abstract}

Keywords: Aboriginal women, missing women, violence, political art, art and activism, advocacy

\section{Introduction}

We are two Indigenous women academics living and working on the traditional unceded, ancestral territory of the Musqueam Coast Salish Nation at the University of British Columbia (UBC) in Vancouver, British Columbia (BC). Shelly is a citizen of the Saulteaux Nation and has Norwegian ancestry. She is a social work academic and activist currently researching the efficacy of First Nations Courts in Canada, the abysmal education provided to urban First Nations children in Canada's child protection systems, and researching what it means to Indigenize the international academy. Alessandra is a Brazilian artist, activist and scholar of mixed heritage (Carijó of the Guarani Nation, African and European). She is interested in the role of artists and intellectuals in society; in the intersections between art and activism; and in the representation and self-representation of Indigenous peoples. She is currently working on research on displacements and wandering.

This article developed because of our shared examinations into the factors that make the

Corresponding author:

Shelly Johnson (Mukwa Musayett) Assistant Professor, School of Social Work University of British Columbia, Vancouver BC 604.822.9647

shelly.johnson@ubc.ca
Americas unsafe for Indigenous women, and our determination as scholars and activists to work with artists to advocate for change. This article provides examples of activists, artists and intellectuals who speak up and act up on behalf of murdered and disappeared Indigenous women of the America's, specifically Mexico, Guatemala 
and Canada. It asks "Who speaks for the voiceless?" and "What is the role of art, activism and advocacy for redress and the reparation of loss of so many Indigenous women?"

\section{Who Speaks for the Voiceless?}

While marking violence against Indigenous women in the Americas many trajectories converged, not just the personal histories of two scholars working at UBC. It includes our Indigenous understandings of the hemispheric history of the Americas, north to south, including a history of colonization and neo-colonization, and subsequent history of violence. However it also marks the convergence of our healing, resistance to the violence against Indigenous peoples, and our determination to remember the thousands of Indigenous women that are silenced by their death. We asked each other "How do we accomplish the impossible? How do we redress or repair such great loss"?

\section{Art and Activism}

How does the activist, artist and the intellectual address violence and violations of human rights? How does one write about a reality so grim? How do we address real loss and grieve in communities that have been historically oppressed? Those are some of the questions that come to mind when pondering the historic, social, legal, political and economic conditions that led to our collaboration.

We wonder if art still offers spaces for critique and public intervention. As part of the public sphere, is art still a political tool of challenge, contestation, and negotiation? How does the public space offer a dialogue about history? What are the cultural tactics artists apply for questioning violence? What are the actual possibilities of protest and activism, given the constraints of a reality imbued with the legacy of colonization, and with the violence that arises from such legacies? And what is the position of art amidst complicity?

Our point of departure is the notion that art, as part of a public sphere, offers a forum for discussion of social problems. Artists, whether openly engaged in the discussion of social issues or not, willingly or inadvertently participate in a public debate on the ramifications and consequences of history. Of course, there are questions surrounding the production, dissemination and reception of art, including the social and material conditions that frame such cycles of cultural production. Nevertheless, one may claim that art that addresses social issues is a denunciation of power imbalances and injustices, or at least an invitation to question inequalities. A detailed discussion of the ethics of artistic practice is beyond the scope of this article, but in general this essay addresses questions pertaining to how artists negotiate violations of human rights.

Artists who are activists value an artistic practice that is related to and / or is imbued with a social practice, in fact, often the distinction may seem imperceptible. Artists/ activists do not seek to reproduce the social dynamics in society, but to question social injustices and atrocities, and ultimately they seek to promote human rights.

There is an ongoing debate in the art world discussing what actually entails political or socially engaged art, and of what are the actual possibilities of art that promotes real social and policy changes. Obviously the question of the actual social impact of art is crucial for those interested in positive change, but it is also important to consider that intersections of art and activism have a social impact over time. Once an artist acknowledges social responsibility, said artist can already 
First Peoples Child \& Family Review, Volume 7, Number 2, 2013

engage with the public, therefore resisting the pervasive complicity that plagues our social reality. To put it simply, we are all complicitous until we do something about it; and creating art that begs for a public discussion of important social issues is a palpable act of social action. In the case in point here, the mostly ignored murders of Aboriginal women are at stake, and are part of a community, artistic, and scholarly discussion.

\section{A History of Invisibility}

Recent scholarship has addressed the fact that all over the world women have been victims of violence in a large scale (during war time and peace time), including rape, torture and murder (recent examples in Bosnia-Herzegovina, Rwanda, Liberia, and Sierra Leone) (Fregoso \& Bejarano, 2010). Narrowing it down to a hemispheric context, this article will focus on crimes against women in the Americas. One of our goals is to establish points of contact between different Indigenous communities that suffer similar histories of oppression and violence. In this vein, it is possible to create what Macarena Gómez-Barris (2012) has called a hemispheric interconnectivity and solidarity that disarticulates the United States hegemony that has long defined the Americas. The history of crimes against women that go on in the Americas with impunity is symptomatic of a legislative blind spot, of a lack of social action, and of a deliberate choice from the part of the authorities to ignore reality. The fact that women are being murdered across the Americas is perhaps to some enough reason to be indifferent, but the fact that Indigenous women are being murdered across the Americas is even more reason to ignore the facts, to pretend the Indigenous women are invisible. The denial of investigation and persecution in the cases in question is proof that the justice system privileges a segment of society, and Indigenous women are certainly at the bottom of the social stratification. The impunity continues the legacy of colonization, as part of "the dominant and subordinate dynamic at the heart of the modern/colonial divide" (GómezBarris, 2012, p.122).

The term feminicide refers to the murder of women and appears in a small but significant scholarship. In the particular case of Latin America, the use of rape and murder of women has been systemic and persistent for great part of the 20th century, and continuing into the 21 st century, including cases in El Salvador, Peru, Haiti, Honduras, Colombia and Guatemala (Fregoso, 2010). Two particular examples of murders of women that have reached epidemic proportions take place in Mexico and Guatemala. Of course the horrible phenomenon known as feminicide does not only affect women of Indigenous origin in these countries, but since in Mexico and Guatemala the majority of the population is of mixed origin (Fregoso \& Bejarano, 2010), most women murdered in Mexico and Guatemala are of Indigenous origin.

\section{Colonial History and Decolonization}

Before discussing these two national cases, however, it is important to contextualize their location within a larger hemispheric history. Without a doubt, the history of the colonization of the Americas has been a history of violence, including slavery and genocide of Indigenous peoples by European colonizers. In some ways, while addressing contemporary violence against Indigenous women, we are addressing the legacy of such history, as well as the history of processes of re-colonization, and of neo-colonialism. Contemporary artists, activists and scholars have promoted ways in which the process of decolonization may take place, particularly through finding voices from Indigenous communities that exist throughout the Americas. One example 
is the scholar and activist Silvia Rivera Cusicanqui, of the Aymara Nation, who uses Aymara and Quechua cosmologies in her work as sociologist and historian in Bolivia.

According to Cusicanqui (2006), the struggles of Indigenous communities in the Americas have also presented and proved a history of resistance that is important to recognize. In a project of reclaiming the Indigenous nations' own historicity, Cusicanqui proposes a process of decolonization that entails imagining a solidary community that reclaims forms of selfrepresentation. In order to do so, Indigenous peoples need to find strategies that create a language of empowerment.

Cusicanqui (2006) makes the claim that Indigenous communities have been referred to in art and scholarship as primitive, as remnants of the past, or as essentialized figures of noble savages connected to nature. Instead, she proposes a claiming of an Indigenous historicity that declares an Indigenous contemporaneity, for we live in a present where Indigenous cultural practices are just as contemporaneous as any. In order to do that, Cusicanqui proposes a "decolonization of the imaginaries and of forms of representation" (2006, p.120). Later in this article, the REDress project in Canada is offered as one example of a decolonized practice that reclaims a voice and agency to missing and murdered Indigenous women victims of violence and discrimination.

Another pitfall of current neo-colonialism that Cusicanqui addresses is the problematic of multiculturalism. According to the Aymara critic, multiculturalism denies ethnicities through a homogenizing posture of acknowledging diversity, therefore functioning as "a hiding mechanism par excellence of new forms of colonization" (Cusicanqui, 2006, p.6). Along these lines, multiculturalism does not provide inclusion, but in actuality essentializes Indigenous issues in service of the interests of the state through a transformation of Indigenous populations into subjects of history without agency. She makes the claim that multiculturalism has been coopted and that "a discourse of decolonization, a theory of decolonization, cannot exist without a decolonizing practice" (Cusicanqui, 2006, p.7). In the context of the issue at stake here, the violence against Indigenous women will not end until the practice of oppression against Indigenous peoples discontinues. Such oppressive practices take many forms and it has been implemented from top down politics, making it ubiquitous and difficult to resist. In the case of both Canada and Latin America, issues of discrimination and racism are actualized through structural discrimination that keeps Indigenous populations poor, preventing the insertion and social mobility of marginalized Indigenous populations into society; isolation and separation of families through the reserve system or residential schools system (in the case of Canada); and assimilation of European culture through processes of social validation that privilege European knowledge, laws and politics. These are only but a few variables which perpetuate forms of colonialism that have existed for centuries in the Americas.

Therefore, the murder of Indigenous women is yet another aspect that factors in the ongoing discrimination and oppression of Indigenous communities across the hemisphere, a brutal and tragic reality that is ignored for the most part. While faced with atrocious crimes against Indigenous women - a largely unspoken and silenced subject-there may be an impression that nothing can be done about it. Artists have taken upon themselves to find strategies in which to make the invisible visible. 


\section{The Case of Mexico}

Like many countries in Latin America, Mexico has had a history of violence and colonization, as well as a history of authoritarism and oppression. Indigenous communities in general have suffered in a country of a majority of citizens of mixed origin (Indigenous and European among other ethnicities). Arguably, the participation of Mexico in the North American economy has increased social inequalities, and the problem of violence against women. In July 2012 Amnesty International announced that:

according to a report published by UNIFEM and local human rights organizations, at least 34,000 women were murdered in Mexico between 1985 and 2009-2,418 in 2010 alone. In the state of Chihuahua, where there was a sharp increase of murders, in 2010 one of every 11 victims was a women - up from one in every 14 in 2008. In Ciudad Juárez, 320 women were murdered in 2010. The number of killings fell back slightly in 2011. In the first six months of 2012 there were more than 130 killings of women in the state of Chihuahua. In 2009 alone, public prosecutor's office round the country received 14,829 reports of rape - an alarming number considering that most women do not report these crimes. Only 2,795 convictions were achieved in the courts (Knox, 2012).

As the above quote evidences, the most noticed case of violence in Mexico is in the northern city called Ciudad Juárez. Juárez is located at the state of Chihuahua, and it borders with the United States city of El Paso in Texas. Due to its geographical location, obviously the city of Juárez has the characteristics of a border town, where traffic and criminality are rampant, as well as poverty and the presence of slums. In addition, and as a result of a global economy and free trade agreements between the two countries in question, Juárez is an industrial site that has seen the proliferation of gigantic factories in the past few decades. The maquiladoras as these factories are known in the area, are mostly deregulated because they operate in free trade zone. The sort of social inequalities these deregulations cause has increased poverty and violence even more.

Since 1993, Juárez has also been the site of murders of hundreds of women every year, amounting to thousands of women. Some murders were related to drug traffic and gang related activity, but not all. Many of the women murdered in Juárez were also victims of rape, many worked for the maquiladora factories, and most were of Indigenous origin. As it is the case in most of the Americas, the vast majority of the murders of women that continue to occur for 20 years in Juárez go on with impunity, without investigation, persecution, or justice. There have been activists, journalists and artists responses, availing to little consequences to the authorities.

\section{How do Artists Deal with it? Roberto Bolaño and Teresa Margolles}

Chilean born writer Roberto Bolaño (1953-2003) has received much critical and public acclaim for his novels after they were published posthumously in English after 2004. Bolaño has become one of the most important contemporary Latin American writers, and he may certainly be considered an activist of Indigenous and women's rights through his work. Many of his novels deal with issues regarding authoritarian regimes, violence, and discrimination, as well as the colonization and neo-colonization of his native Chile, and he often included stories about the Mapuche resistance to Spanish colonization in his narratives. He also named his son Lautaro, in homage to a 16th century leader in the Mapuche nation resistance. In his literary novel 2666 (2004) Bolaño offers a fictional world that documents the historical atrocities against the women 
of Juárez, with wide implications on the violence and border politics between the United States and Mexico. Bolaño confronts the reader with historical acts of extreme violence that, unlike dictatorships and civil wars, are decentralized and could happen anywhere to any woman.

In a complicated novel, the main thread that links all characters and stories is a place in Mexico, a fictitious city called Santa Teresa, which is an apocalyptic border town modeled after the real Ciudad Juárez. In the brutality of stories filled with confrontation, Bolaño describes page after page the murdered women's bodies, the victims from Ciudad Juárez' crimes. Based on the non-fiction book Huesos en el desierto (2002) by journalist Sergio González Rodríguez (who is also a character in 2666) the novel's chapter on the crimes is a detailed account of the victims' corpses. In an almost insufferable narrative, Bolaño manages to give names and histories to over a hundred victims in one year of the tragic history of Juárez.

Bolaño's novels often question the role of the artist and the intellectual, and point towards a direction indicating that the author might not believe in the role of the intellectual in society. Nevertheless, his moral preoccupations in relating these crimes against women point to an opposite direction. Bolaño's writing offers tactics of negotiating Mexican reality and violence. To critics, Bolaño has helped internationalize these local crimes, saying that "this novel helps situate these phenomena in a wider global context" (Herlinghaus, 2011, p. 116); or that Bolaño has faced "the utter terror that is called contemporary living" (Franco, 2009, p. 207).

In the novel, the city of Juárez is a character in itself, described as an infernal place where women are never safe, but it is also the site of protest by feminist groups, and of journalistic investigations, despite the danger. It is the character Florita Almada, an Indigenous shaman, who calls that "the silence must be broken...", that "such terrible apathy and such terrible darkness" must end (Bolano, 2008, p.437). A character largely ignored by other critics, it's through the healer Florita and her visions that action is called upon, and the notion of resistance is proposed amidst drug and gang wars, border poverty, the maquiladoras' harsh reality, and the fact that in Mexico politics intertwined with drug traffic lead to unsolved crimes against women. Santa Teresa/ Juárez is "a sketch of the industrial landscape in the third world" (p. 294). Ironically, to Bolaño freedom is to blame. In an interview, Bolaño mentioned that Ciudad Juárez was his vision of hell, "our curse and mirror, the restless mirror of our frustrations and our infamous interpretation of freedom and our desires. What curbs that unrestricted freedom that leads to violence? Not religion or political belief, nor some universal precept" (quoted in Franco, 2007, p. 215). In denouncing the crimes against women in Juárez, not only does Bolaño expose the reader to a horrific contemporary history, but he also questions issues of social responsibility.

In a different approach, Mexican artist Teresa Margolles (born in 1963) also confronts the crimes against women in Ciudad Juárez. Margolles is known for investigating the consequences of crime and violence in Mexico, and she worked in an art collective that used forensic materials to make art. For example, she built a concrete table using water from a morgue that had been used to wash corpses. Particularly in her work about the crimes in Juárez, Margolles attempts to be an artist who is a "deputy to the dead," giving a body and a history to the invisible corpse, and a voice to the voiceless (Bray, 2007, p. 4). Like Bolaño, Margolles wants to evidence the crimes that go unpunished, but unlike the writer, Margolles works with testimony and images.

Among her series of works about the dead women in the Mexican city, Margolles went to Juárez in 2005 and, according to Rebecca Bray "drove to the crime scenes of a number of murders, where she spent time at the site, often many nights. At these crime scenes she collected the earth; with the earth she produced 500 stones" (2007, p. 28). Margolles' art piece entitled Lote Bravo (2005) 
First Peoples Child \& Family Review, Volume 7, Number 2, 2013

deliberately renders material the invisible presence of the dead. If the dead women are no longer remembered, except for those who mourn them, Margolles takes upon herself the task to bring the dead back to the physical realm. In his novel about the Juárez dead women, Bolaño's words painstakingly and methodically describe corpse after corpse of the victims in details. Margolles' work, on the other hand, does not offer details, but works in a sort of a "material abstraction," using the materials close to the dead women, the earth, to create new objects in the shape of bricks-building blocks of a new future where Indigenous women are no longer killed.

More recently, in early 2012, in a show called Broken Borders at the Satellite Gallery in Vancouver, Margolles exhibited a video art piece called Irrigation (2010). For the video, Margolles soaked blankets in the blood and bodily fluids of the dead women from Ciudad Juárez, later soaking the blankets in a large quantity of water which was placed in a water truck that sprayed a highway road in Texas. The video shows the water truck's journey across the border, carrying the fluids of the dead women, transporting the dead in its remains. Margolles reflections extend the problematic of the crimes against women to border issues. Clearly the crimes of Juárez are a product of intense social inequalities and international tensions that entail drug traffic and other transborder activities. The presence of the dead women is materialized through Margolles words, physically and conceptually, and the artist's pieces function as poetic protests and denunciation.

\section{The Case of Guatemala}

According to Amnesty International Reports, Guatemala has the worst record for violence against women, not only in the Americas, but it has the world's highest rate of feminicide. Historically, Guatemala, like many countries in Central America, has had a history of brutality. The majority of the population in Guatemala is of mixed heritage (Indigenous and European), and a large portion of the population is Indigenous (40 per cent). During a violent civil war that lasted 36 years (1960-1996), the Indigenous communities, and particularly the women suffered the most. It is now known since "truth commissions set up after peace accords were signed in 1996 found that some 200,000 people had been killed or had disappeared during the civil war, and that government forces committed 626 massacres in indigenous villages and the rape and murder of Indigenous women" (Malkin, 2012). Now Guatemala is finally under the process of persecuting and trying former military for war crimes and genocide, like several countries in Latin America.

Unfortunately, crimes against humanity have not stopped after the end of the civil war in 1996. Guatemala currently suffers from problems of violence, particularly gang related, and "pervasive and systematic violence against women committed with impunity" (Musalo, 2011, p. 3). According to the Women's Law report from 2010 "in Guatemala, this violence has reached epidemic proportions. During the past decade, over 4,000 women have been killed. There have been successful prosecutions in no more than 2 per cent of these cases, meaning that 98 out of 100 killers of women literally get away with murder" (Musalo, 2011, p. 3).

\section{How do Artists Deal with it? Regina José Galindo}

One example of an artist from Guatemala who addresses crimes against indigenous women is poet and performance artist Regina José Galindo (born in 1974). In Galindo's work the body is often at stake, staging reminders of violence. Galindo's body functions as a witness that reflects 
Guatemala's turbulent history and brutalities, and it's a living testament to how the transition to democracy in Guatemala has still brought violence and inequalities. Galindo's main preoccupation is "inscribing inerasable memories," embodying crimes that still take place on a daily basis, but are again for the most part, invisible. Galindo studies the effects of persistent violent and social inequalities through her own experiences.

To mention one example of how Galindo has discussed the appalling situation of the murder of women in Guatemala, at the Venice Biennale, she hid behind a screen, and using a leather belt, she proceeded to hit herself for each woman who was murdered in Guatemala from January 1 to June 9 2005, in a total of 279 blows (Golpes 2005). The public only hears the amplified sounds. This performance of self-flagellation attests to the obscene quality of the murders, by literalizing the hidden element. No one can see the horrible crimes committed. Galindo has also cut the word "bitch" on her left thigh in a performance that emulates messages that gang members inscribe on the bodies of dead women (Perra 2005). She also had her body thrown in a land fill inside a plastic bag, as happens to many murder victims (No perdemos nada con nacer 2000). In addition, Galindo has a series on normative standards of beauty, and expectations on women's appearances, such as a performance where a plastic surgeon pointed out all the "problems" in her body, for example in Recorte por la línea (2005). Galindo is interested in larger issues of social pressures that women have to endure to conform to standardized bodies, as well as on the constant danger that women in Guatemala suffer.

What is striking about Galindo's performances is that her small stature is submitted to trials and endurance. Nevertheless, as Virginia Pérez-Ratton pointed out "Galindo's work is not only about the artist's particular act of endurance but, more importantly, about how much the individual spectators in their own right come to understand, and even endure, a violent reality through the performance" (2007, p. 140). Galindo literally takes public risks for the sake of memory and social awareness. She radicalizes public spaces and restricted art spaces, and calls attention to a new inspection of history. In her confrontations and voluntary violations against her body, she creates a shock value because art is not past shock for as long as history is still shocking.

Galindo's positions stem from general politics and her work deliberates on violence against women and their consequences. The issue of violence, particularly when the state does not act to solve the problem, is a community matter. The crimes against women both in Ciudad Juárez and in Guatemala are part of a social reality that for the most part is invisible. Crimes against Indigenous women are crimes against humanity, and they continue to go on in Mexico and Guatemala. The role of the artists under these circumstances is to collectivize their own awareness as a call to action.

\section{The Case of Canada}

Canadian critic Diana Taylor, who was raised in Mexico, and whose main scholarly preoccupations are studying the connections between art and politics, has written extensively about the importance of art in raising consciousness. Taylor (2005) claims that art as embodied practices, such as the art work of Margolles, Galindo or even Bolaño, do indeed transmit knowledge about the past and help shape actual change. Taylor discusses how ephemeral artistic practices expose the past and "fuel cultural agency in the present" (pp. 279-280).

While facing violent realities, especially while facing brutalities that no one (except perhaps for the families and friends of the victims) wants to address, artists and intellectuals have a crucial 
First Peoples Child \& Family Review, Volume 7, Number 2, 2013

role. Artists have a social responsibility to remind communities that crimes exist because of a long historical tradition of oppression, but that they don't have to be repeated. In that sense, artists and intellectuals can work with communities towards the common goal of decolonization, to change oppression and discrimination. What is necessary, from a practical point of view, is not only resistance and protest, but an awareness of the problem and a change in perspective, or what Colombian critic Adolfo Albán Achinte has called re-existence. Achinte defined re-existence as "the devices that communities create and develop to re-invent themselves in everyday life to confront the reality established by the hegemonic project that from colonial times has diminished and silenced and made invisible the existence" of disenfranchised communities (2009, p.13).

The incidence of crimes against Indigenous women in the Americas has a long history in the making, but in remembering this history now, in redressing the invisible violence, in rendering the invisible visible, is how we as community can put a stop to the atrocities. I imagine most people in Canada, specifically here in BC, don't know that Indigenous women were and are deliberately murdered. As Taylor proposed "negotiation, not violence... proves the true heroic strategy" (Taylor, 2005, p. 289). It takes a heroic community to acknowledge violence, and to negotiate with their leaders and those in positions of power. It takes an even more courageous act to say through art that this must stop.

\section{How do Artists Deal with it? Jaime Black's REDress Project}

The REDress project is an art installation creation by Jaime Black, a young female Métis artist in Manitoba. By hanging red dresses on simple wooden hangers in public spaces, Black aims to draw attention to the more than 600 missing and murdered Aboriginal women in Canada. Her aims are two-fold; to initiate critical dialogue about gendered and racialized violent crimes against Aboriginal women in Canada, and to "evoke their presence through the marking of their absence" (J. Black, personal communication, October 5, 2011).

Black took some of her inspiration for the project from her experience in Opaskawayak Cree Nation, located near the small rural community of The Pas, Manitoba. This is the community where nineteen year old Cree high school student Helen Betty Osborne was brutally sexually assaulted, stabbed with a screwdriver more than fifty times, and murdered in 1971. Several months later, Royal Canadian Mounted Police officers concluded that four white men were involved in Betty's abduction and murder. Yet it was not until December 1987, more than sixteen years later, that one of them, Dwayne Johnston, was convicted and sentenced to life imprisonment for her murder. Less than ten years later, on October 10, 1997 Johnston received full parole. James Houghton was acquitted. Lee Colgan received immunity from prosecution in return for testifying against Houghton and Johnston. Norman Manger was never charged (Aboriginal Justice Implementation Commission, 2001).

More inspiration came from a conference in Bogata, Colombia, where Black witnessed a public performance enacted by 300 women in the Place de Bolivar (main square). The performance was to protest violence in their lives, and the loss of family members to politically influenced abduction and murder. This Colombian public performance, conducted by women wearing red dresses, heavily influenced Black's decision to create the REDress public art installation in Canada. The contemporary issue that she chose to invoke and surround with critical dialogue is the 582 missing and murdered Aboriginal women identified by the Native Women's Association 
of Canada (NWAC) in their 2010 research report entitled "Stolen sisters: What their stories tell us".

For Black, the colour red portrays both Indigenous femininity and sexuality. Red also reflects violence and the spilled blood of Indigenous missing and murdered women in Canada. A collaboration between Black and the University of Winnipeg's Institute for Women's and Gender Studies (IWGS) in March 2011 launched a campaign to raise awareness for the murders and disappearances of Aboriginal women across Canada. This was the first REDress art installation on a university campus in Canada. Black worked with the institution to install over 120 red dresses on the campus, provide tours of the installation sites, an artist talk and contribute to a panel presentation. Red dresses in all shapes and sizes were donated to Black from community members, including one from the family of a missing Aboriginal woman. She hung the dresses on simple wooden hangers and affixed them in groups with translucent fishing line wire, both outside and inside the university buildings.

\section{How do Activists Deal with it? Native Women's Association of Canada (NWAC)}

In 2005 as part of their continuing efforts to publicly seek justice and redress for missing and murdered Aboriginal women in Canada, the NWAC created the "Sisters in Spirit" (SIS) project. Each October 4 marks a national day of remembrance to honour the memory of missing and murdered Aboriginal women in Canada and an opportunity to embrace their families, particularly their children. NWAC is instrumental in documenting that more than one quarter of the disappearances and murders of Aboriginal women in Canada have occurred in BC, with a concentration of killings in several locations including Vancouver's Downtown Eastside and along the Highway of Tears (highway 16 west of Prince George to Prince Rupert).

It is important to recognize October 4 in $\mathrm{BC}$ because it is the province in which the first and only Missing Women Commission of Inquiry (MWCI) was appointed into police and criminal justice failures with respect to disappearances and murders of women. A March 2012 press release issued by NWAC and the Canadian Feminist Alliance for International Action (FAFIA) details their profound disappointment and outrage at BC's and the MWCI unwillingness to respect the rights of Aboriginal women to fully and equally participate in the judicial process. NWAC and FAFIA appeared before the Inter-American Commission of Human Rights in Washington D.C. on March 28, 2012 to provide a thematic briefing on the subject of the disappearances and murders of Aboriginal women and girls in $\mathrm{BC}$. The press release states that:

NWAC hoped that the Missing Women Commission of Inquiry would provide an opportunity to shed light on the systemic failures of the police and criminal justice system to deal with the racialized and sexualized violence that Aboriginal women and girls experience and become a model for other jurisdictions. For that reason, NWAC applied for, and was granted, full standing at the Inquiry. Unfortunately, however, both the Government of British Columbia and the Missing Women Commission of Inquiry further violated the rights of Aboriginal women and girls, by refusing NWAC funding for its legal counsel, and by appointing "independent counsel" to speak for Aboriginal women, without our consent. The recently announced decision of that lawyer to withdraw, and her reasons for doing so, confirmed NWAC's worst fear that this Inquiry will not provide answers to the ongoing discrimination against Aboriginal women that threatens their safety and lives. The Missing Women Commission of Inquiry is a failure for Aboriginal women, with 25 publicly-funded lawyers now representing police agencies, no publicly funded counsel 
First Peoples Child \& Family Review, Volume 7, Number 2, 2013

representing any of the groups that were granted standing, and no participation of any Aboriginal groups in the Inquiry (NWAC, 2012).

\section{How do Artist and Activists deal with it? SIS joins with the REDress project}

At the time that Indigenous groups in BC were expressing public criticism of the work of the MWCI, I was working as a faculty member at another post-secondary institution in BC. The Chancellor of institution at that time, Justice Wally Oppal, was simultaneously the Commissioner of the MWCI. Indigenous community members felt it was important for these very political reasons to highlight the institution as the site of one of the planned 84 SIS national vigils on October 4, 2011. Justice Oppal/the Chancellor was invited to participate in a panel discussion; one of a number of events planned for October 4-7, 2011 and he declined.

A new and inclusive community-university based Indigenous Advisory Committee (IAC) was developed to raise funds, recruit and organize volunteers, solicit donations of red dresses, plan, advertise and implement the REDress project. Black was contracted to travel to the small city in August 2011 to determine appropriate installation sites, and meet community and university partners involved in the project. She returned at the beginning of October 2011 to install over 200 red dresses in four community-based sites and three university sites. Perhaps the most visually impactful and meaningful REDress installation for IAC members was hung in a long row of trees stretching in front of the former Kamloops Indian Residential School. The red dresses of various sizes, shapes and vintages moving with the breezes evoked thoughts and memories of so many of the former students, the women they became, and were lost to their families and communities. It was important to organizers that there was an equal amount of Aboriginal organizations and non- Aboriginal organizations involved in the event in an effort to support growing awareness of the issues and to spark critical dialogue between the two populations (university/city and reserve-based).

A local Kamloops newspaper reporter wrote of the T'kemlups Indian band's open public invitation to attend the October 4, 2011 dinner and vigil, "If all things were equal, the unexplained disappearance of hundreds of Canadians would need no added emphasis to attract attention. Yet all things are far from equal in Canada. Aboriginal women aged 5 to 44 are five times more likely to suffer a violent death than other women in Canada" (Youds, 2011).

The news article offers a glimpse into the differential and sometimes problematic ways in which the issue of missing and murdered Aboriginal women and violence against Aboriginal women is portrayed or ignored by mainstream Canadian media. Criticism ranges from charges of indifference, racism and bias in that had the missing women been White, the media coverage would rival that given to serial killers and rapists in the Paul Bernardo-Karla Homolko case. Media responses have been both denials that a race issue or bias exists, to incorporation of the charges of bias and indifference in their coverage (Media Portrayals, 2012). What does seem to be needed is more research such as that conducted by NWAC (2010). That research provides evidence to challenge potential stereotypes held by Canadians, and identifies that most of the missing Aboriginal women are not sex trade workers. In addition research and media coverage needs to focus on explaining how the consequences of larger structural or historic issues such as racism, colonialism, residential school and child welfare trauma, poverty and other socioeconomic and political issues, differentially affects Aboriginal women in Canada. Their educative 


\section{REDressing Invisibility and Marking Violence Against Indigenous Women}

contributions can help to turn the gaze back on structures and systems that perpetuate inequality and lack of redress.

On October 5, 2011 a public film screening of Building a Highway of Hope, occurred twice on the post-secondary campus. The independent documentary was filmed and directed by young Indigenous feminist activist Jessica Yee (Mohawk and Chinese) about the numerous disappearances and murders of Aboriginal women along Highway 16 in BC. The second screening was followed by a public talk by the director who was joined by Jaime Black and included approximately fifteen people who had taken tours of the art installations on campus or visited communitybased sites on and off the Tkemlups Indian Band. On October 6, 2011 a second Indigenous film was screened and followed by a discussion with a community-based panel. Finding Dawn, released in 2006 by Métis filmmaker Christine Welsh, is a National Film Board documentary now available on-line. It discusses the murders and disappearances of 500 Aboriginal women in Canada over the past 30 years and suggests ways to build toward social justice for the women and families. This documentary chronicles Aboriginal women's experiences in Canada's Vancouver Downtown East Side and the Highway of Tears in northern BC. Finding Dawn discusses the historical, social and economic factors that contribute to what the filmmaker calls the epidemic of violence against Native women in this country. Its interviews with Ernie Crey, a Sto:lo fisheries consultant, political actvist, author and brother of murder victim Dawn Crey, whose DNA was discovered on the Pickton Pig Farm in Port Coquitlam, BC contributed to the documentary title. The nearly \$100 million joint RCMP-Vancouver Police Department investigation and trial, the most expensive in Canadian history, led to charges in her death and the deaths of twenty-five others, but charges into the deaths of twenty of the women were subsequently dropped. Pickton was convicted in December 2007 on six counts of second-degree murder and is currently serving a life sentence with no chance of parole for twenty-five years.

The discussion panel included an elder from the Tkemlups Indian Band, a representative from the NWAC, a family member of a disappeared woman and a First Nations lawyer. Interestingly, the lawyer drew a comparison between her environmental work into the disappearances of Fraser River salmon stocks in BC and the disappearances of Aboriginal women in BC. She commented about the lack of financial or legal resources provided by governments to search for Aboriginal women who go missing or provision of legal representation to support the meaningful inclusion of Aboriginal women and Aboriginal organizations at the MWCI. However, she did note that when salmon stocks went missing in 2009, in 2010 the BC government did financially support First Nations communities and organizations to participate at the Vancouver-based Cohen Commission of Inquiry as it launched its official investigation into the collapse of sockeye salmon stocks in BC's Fraser River. It was a comparison that clearly articulated the BC government's economic worth of salmon and lack of value of First Nations women. Unfortunately less than 50 people attended the film screening and panel discussion in a theatre able to seat 300 . The REDress art installation ended on October 7, 2011 with two tours and an artist talk by Black .

\section{Addressing a Human Rights Crisis, a National Disgrace, Unacceptable Numbers and an Unacceptable Canadian Response}

For Sharon McIvor, a First Nations lawyer and member of FAFIA, the disappearances and murders of more than 600 Aboriginal women and girls across Canada is a human rights crisis that requires relentless advocacy by Indigenous women and organizations. Her way forward is to call on "Governments at all levels that have not put in place the measures necessary to discharge 
First Peoples Child \& Family Review, Volume 7, Number 2, 2013

their obligations to prevent, prosecute, investigate and remedy this violence". On March 28, 2012 she asked the Inter-American Commission on Human Rights to initiate a National Inquiry on missing and murdered Aboriginal women and girls that:

will lead to the design of national, cross-jurisdictional mechanisms and protocols for police and justice officials and to an action plan that will address the crisis of violence, and the social and economic disadvantages of Aboriginal women and girls - including poverty, inadequate housing, low educational attainment, inadequate child welfare policies, and overcriminalization; ensure inter-jurisdictional and inter-agency coordination of policing and law enforcement and establish improved federal, provincial, and territorial police accountability mechanisms that include both civilian oversight and civilian investigation, particularly for adherence with constitutional requirements of equal protection and access to justice; establish a federal mechanism for investigations into misconduct and discrimination within the criminal justice system and police forces; co-operate with civil society groups endeavoring to end violence against Aboriginal women and girls in Canada and ensure the full participation of Aboriginal women and Aboriginal organizations, with representatives of their own choosing, within national and provincial inquiries and any other related commissions or inquiries dealing with their rights (NWAC, 2012).

The NWAC (2010) research report identified 582 missing and murdered women in Canada on their Sisters in Spirit database, and listed the intergenerational impact from colonial and state policies such as residential schools and child welfare as contributing factors in the violence they experienced. The organization found that over two thirds of the women are from BC, Alberta, Saskatchewan and Manitoba, more than half are under the age of 31 and over 70 per cent disappeared from urban areas. Further, their research identified that "many of the women were mothers. Of the cases where this information is known, 88 per cent of missing and murdered women and girls left behind children and grandchildren" (NWAC, 2010, p.ii). In the two short years since NWAC's 2010 report, the Federal Conservative Government has severely cut its health portfolio, research capacity and SIS vigil support and reallocated the funding to beef up police technology. This action, in the view of NWAC speaking on behalf of marginalized Aboriginal women, will do little to improve safety for Aboriginal women and girls in Canada.

As of September 6, 2012 the NWAC reports that Canada has further cut the NWAC core funding that was not increased since 2005. It is a predictable response from Canada which bristles at the evidence developed by Aboriginal women that Canada's reputation as a fair and just society is unwarranted and suspect. This seems to be particularly true when Canada is confronted with growing calls for meaningful support and participation by Aboriginal women and organizations in matters directly affecting us.

\section{Conclusion: How do Academics deal with it? Working with Artists and Activists to Educate, Raise Awareness and Work Towards Redress}

This article provides examples of the inspiring and inclusive numbers of ways that Indigenous artists, activists, writers, academics, lawyers, social workers, community based organizations, family members, international bodies and others continue to seek redress, social justice, health, economic and physical safety for Indigenous women in the America's. Individually and collectively they are taking steps to highlight the murdered and disappeared Indigenous women and girls in the America's, despite limited resources, disrespectful or widespread lack of knowledge about 


\section{REDressing Invisibility and Marking Violence Against Indigenous Women}

the issues and retaliatory aggression from states. The ongoing lack of redress demonstrates that more must be done to educate the general public and address long-standing and contemporary concerns. Despite the overwhelming barriers to redress and healing, Indigenous voices continue to be heard, Indigenous art and activism exists, and continues to counteract the overwhelming mainstream silence. In these Indigenous voices and actions, lives resistance and determination for change. In addition, Indigenous concerns and solutions continue to find many ways into non-Indigenous mainstream and ally spaces, academic venues and attention in national and international forums.

\section{References}

Aboriginal Justice Implementation Commission. (1999). Report of the Aboriginal Justice Inquiry of Manitoba. Retrieved from http://www.ajic.mb.ca/volume.html

Achinte, A. A. (2009). Artistas indígenas y afrocolombianos: entre las memorias y las cosmovisiones. Arte y estética en la encrucijada descolonial. Z. Palermo \& W. Mignolo (Eds.). Buenos Aires: Del Signo.

Bolaño, R. (2008). 2666. Natasha Wimmer, trans. New York: Picador.

Bray, R. S. (2007). El piel ajena: The work of Teresa Margolles. Law Text Culture, 11,1.

Canadian Press. (2010, November 16). Serial killer Robert Picktons trial cost $\$ 102$ million. CTV News. Retrieved from http://www.ctvnews.ca/serial-killer-robert-pickton-s-trial-cost-102-million-1.575485.

Cohen Commission of Inquiry (2010). Participants granted standing. Retrieved from http://www.cohencommission. ca/en/Participants.php.

Cusicanqui, S. R. (2006). Ch'ixinakax utxiwa. Una reflexión sobre prácticas y discursos descolonizadores. Modernidad y Pensamiento Descolonizador. M. Yapu (Ed.) La Paz: Universidad para la Investigación Estratégica en Bolivia, 1-16.

Franco, Jean. (2009). Questions for Bolaño. Journal of Latin American Cultural Studies Travesia, (18), 2, 3.

Fregoso, R.L. \& Bejarano, C. (2010). Introduction: A cartography of feminicide in the Americas. In Terrorizing Women: Feminicide in the Americas. Fregoso. R.L. (Ed.). Durham: Duke University Press.

Galindo, R. (2005). Golpes. Retrieved from http://www.reginajosegalindo.com

Galindo, R. (2005). Perra. Retrieved from http://www.reginajosegalindo.com.

Galindo, R.(2005). Recorte por la línea. Retrieved from http://www.reginajosegalindo.com

Gadindo, R. (2000). No perdemos nada con nacer. Retrieved from http://www.reginajosegalindo.com.

Gómez-Barris, Macarena. (2012). Mapuche hunger acts: Epistemology of the decolonial. TRANSMODERNITY: Journal of Peripheral Cultural Production of the Luso-Hispanic World, 1 (3). 120-132.

González Rodríguez, S. (2002). Huesos en el desierto. Barcelona: Anagrama.

Haig-Brown, C. (1988). Resistance and renewal: Surviving the Indian residential school. Vancouver: Arsenal Pulp Press.

Herlinghaus, H. (2011). Placebo intellectuals in the wake of cosmopolitanism: A 'pharmacological' approach to Roberto Bolaño's novel 2666. The Global South, 5(1).

Hutchinson, B. (2012, August 10). Missing Women inquiry workers paid more than B.C.'s longestserving judges. National Post. Retrieved from http://news.nationalpost.com/2012/08/10/ missing-women-inquiry-workers-paid-more-than-b-c-s-longest-serving-judges/ 


\section{First Peoples Child \& Family Review, Volume 7, Number 2, 2013}

Knox, R. (2012). Mexico fails to tackle increased levels of violence against women. 12 July 2012. Accessed on October 22, 2012. Retrieved from http://www.amnesty.org/en/news/

Lambert, S. \& Duncombe, S. (2012). An open letter to critics writing about political art. Center for Artistic Activism. Accessed on October, 222012 from http://artisticactivism.org/2012/10/ an-open-letter-to-critics-writing-about-political-art/

Margolles, T. (2010). Irrigation. Retrieved from http://satellitegallery.wordpress.com/2012/03/25/ broken-borders-breaking-borders/

Marglles, T. (2005). Lote Bravo. Retrieved from http://www.mfah.org/art/detail/margolles-lote-bravo/

Malkin, E. (2012). In Guatemala, Former Dictator Is Told to Appear in Court. New York Times, January 22, 2012.

Media Smarts. (2012). Media portrayals of missing and murdered Aboriginal women. Retrieved from http:// mediasmarts.ca/diversity-media/aboriginal-people/media-portrayals-missing-and-murdered-aboriginal-women

Missing Women Commission of Inquiry. (2012). Retrieved from http://www.missingwomeninquiry.ca/Musalo, K., \& Pellegrin, E. \& Roberts, S. (2010). Crimes without punishment: Violence against women in Guatemala. Hastings Women's Law Journal, (21), 1, 161-221.

Native Women's Association of Canada. [NWAC]. (2010a). What their stories tell us. Retrieved from http://www. nwac.ca/sites/default/files/imce/2010_NWAC_SIS_Report_EN.pdf

Native Women's Association of Canada. [NWAC]. (2010, November 9b). NWAC responds to \$10M announcement from the Department of Justice Canada. Retrieved from http://www.nwac.ca/sites/default/files/imce/Press $\% 20$ Release_NWAC\%20responds\%20to\%20\$10M_9\%20November\%202010.pdf

NWAC. (2012, March 27). Inter-American Commission on Human Rights holds hearing on disappearances and murders of Aboriginal women and girls in British Columbia. Retrieved from http://www.criaw-icref.ca/sites/ criaw/files/NWAC\%20and\%20FAIIA\%20-\%20\%20March\%2027\%202012.pdf.

Pérez-Ratton, V. (2007). Central American women artists in a global age. In Global Feminisms New Directions in Contemporary Art, M. Reilly \& L. Nochlin (Eds.). New York: Brooklyn Museum.

Taylor, D. (2005). Performing the claim: Cultural agents act out in Tepoztlán. Review: Literature and Arts of the Americas, 71.38 (2), 277-289.

Taylor, D. \& Constantino, R. (2003). Holy Terrors: Latin American Women Perform. Duke University Press.

Welsh, C. (2006). Finding Dawn [Motion picture]. Canada. Retrieved from http://www.nfb.ca/film/finding_dawn/

Yee, J. (2010). Highway of hope. [Motion picture]. Canada. Retrieved from http://profileengine.com/groups/ profile/431891147/building-a-highway-of-hope-the-documentary

Youds, M. (2011, October 3). Seeing beyond red: Where have they gone, all these hundreds of missing women? Kamloops Daily News. Retrieved from http://www.kamloopsnews.ca/article/20111003/KAMLOOPS0101 /111009979/-1/kamloops/seeing-beyond-red-where-have-they-gone-these-hundreds-of-missing 